\title{
Mühendislik Eğitimi ve Yükseköğretimde Kalite Güvence Ölçütleri
}

\author{
Ferhat Güngör ${ }^{1 *}$, Ayhan Etyemez ${ }^{2}$ \\ ${ }^{* 1}$ Dr. Öğr. Üyesi Marmara Üniversitesi. fgungor@marmara.edu.tr \\ ${ }^{2}$ Dr. Nikken Türkiye, ayhan@nikken.com.tr
}

\section{Özet}

Ülkelerin gelişebilmeleri için önemli unsurlardan biri nitelikli meslek eğitimi veren yükseköğretim kurumlarının varlığıdır. Ülkemizde mühendislik fakülteleri bu elemanları yetiştiren önemli Lisans düzeyindeki kuruluşlardır. Ülkemizde, belli ölçütlere göre bölüm ve program açma ile öğrenci alımı yükseköğretim kurumunun onayındadır. Bu programların açıldıktan sonra amaca uygun kalite denetimleri, yayımlanan kalite güvence yönetmeliğine göre değerlendirilmektedir. Yükseköğretim kurumlarında, kalite güvenceye ait değerlendirme a) eğitim-öğretim, b) araştırma faaliyetleri ve c) idari hizmetlerin (yönetim) iç ve dış kalitesinin sağlanmasına yönelik üç alanda yürütülür. Ülkemizde de kalite güvence yönetmeliğine göre yükseköğretim kurumlarının dış değerlendirmesi birim/program düzeyinde, iç değerlendirme ve akreditasyon gibi, konularda en az 5 yılda bir yapılmaktadır.

Yükseköğretimde, Mühendislik eğitimi ile amaçlanan, ülkemizdeki insan kaynağını istihdam edilebilir, işverenlerin ihtiyacına ve mesleki yeterliliğe uygun, ülke ekonomisine, insanlığa dolaylı ve doğrudan fayda sağlayan, nitelikli, yazılım ve teknolojiyi kullanan mezunlar vermek olarak tanımlayabiliriz.

$\mathrm{Bu}$ çalışmamızda, yükseköğretimde ki genel eğitim kalitesinin belirlenen ölçütler ile nasıl izlenip, değerlendirilebileceği üzerinde durulmuş ve bir üniversitede birim/ programların önem ve önceliklendirmesine göre temel kalite ölçütleri ve standartlarının değerlendirmesi örneklerle anlatılmıştır.

Anahtar Sözcükler: Kalite Güvence, mühendislik eğitimi, kalite ölçütleri.

\section{Engineering Education and Quality Assurance Criteria in Higher Education}

\begin{abstract}
One of the important elements for the development of countries is the existence of higher education institutions providing qualified vocational education.In our country, engineering faculties are important Bachelor level institutions that train these elements. In our country, students are required to open departments and programs according to certain criteria and they are approved by the higher education institution. After the opening of these programs, the purpose-oriented quality audits are evaluated according to the published quality assurance regulations. In higher education institutions, the evaluation of quality assurance is carried out in three areas: a) education, b) research activities and c) administrative and internal services (management). In our country, external evaluation of higher education institutions according to the quality assurance regulation is carried out at the unit / program level at least every 5 years in terms of internal evaluation and accreditation.

In higher education, it is aimed to employ human resources in our country, employing qualified, software and technology that provides indirect and direct benefits to the country's economy and humanity, suitable for employers' needs and professional competence.

In this study, it was emphasized that the general education quality in higher education can be monitored and evaluated with the determined criteria and the evaluation of the basic quality criteria and standards of the units / programs in a university were explained with examples.
\end{abstract}

Key Words: Quality Assurance, engineering education, quality criteria.

\section{Giriş:}

Mesleki eğitimle amaçlanan, ülkenin insan kaynağını mesleki ve teknolojik yönden istihdam edilebilir ve yeterli eğitim süreçlerinden geçirerek mezun etmek olarak tanımlıyorsak, mesleki eğitim ve öğretimin sonunda öğrenme gerçekleşiyorsa, bu kavramların ne olduğunu açıklayarak başlayalım.

Öğrenme; mesleki eğitim-öğretim süreçleri sonunda öğrencide kalıcı izler bırakan ve meslekle ilgili olumlu davranış değişikliği olarak tanımlanabilir. Eğitim ise; En genel anlamda, bireyde davranış değiştirme sürecidir.[1] Şeklinde tanımlanmıştır. İstemli bilgi, beceri ve kültürel değişim için bireyin planlı süreçlerde çaba sarf etmesidir. Bir makine mühendisliği fakültesine giden öğrencinin, kendi gelişimi için Matlap kurslarına, CAD/CAM seminerlerine gitmesi gibi. Öğretim ise; belli amaçları *Corresponding author: Address: Faculty of Technology, Department of Mechanical Engineering Marmara University, 34722, İstanbul TURKEY. E-mail address: fgungor@marmara.edu.tr, Phone: +902163365770/1676 
gerçekleştirmeye dönük planlı ve programlı bir süreç olarak tanımlanır. Öğretim sürecini incelediğimizde, dört temel alt sürecin olduğunu görmekteyiz: a) Hedeflerin belirlenmesi alt süreci, b) İçerik oluşturma alt süreci, c) Eğitim alt süreci ve d) Değerlendirme alt süreci.

Öğretim sonucunda öğrenciler meslekleriyle ilgili olumlu ve uygun davranış değişikliği kazanırlar. Ĕgitim ve öğretimden amaç; mesleki ve bilimsel gerçeğin öğrenilmesidir.

Öğretme ve Öğrenme süreçleri nelerdir? diye bakıldığında;[2] Şu şekilde sıralayabiliriz; 1) Mesleki eğitimi ve Dersleri Planlama süreci 2)Eğitim Materyali Hazırlama süreci 3) Mesleki eğitimle ilgili öğrenme Ortamlarını Düzenleme süreci, 4) Eğitim (Ders) Dışı Etkinlikler (Teknik gezi, staj yerleri vb) organize etme süreci, 5) Öğrenci farklılıklarını önemseyerek Öğretimi Çeşitlendirme süreci, 6) Mesleki eğitimi Zaman Yönetimi ile yürütmek süreci, 7) Derse katılım ve özgüven kazandırıcı davranışları paylaşım süreci.

Eğitimde kalite nedir? Eğitimde Kalite; 'eğitim faaliyetleriyle, istihdamdaki amaca uygun en iyi mezunları vermektir' şekilde tanımlanır.

'Mükemmelin daima mükemmeli vardır' ilkesi ne tasarımların, ne teknolojilerin, ne de yazılımların ilk durumlarında olmadıkları ve çok daha gelişmiş durumda oldukları bir gerçektir. Bu gün için elimizdeki mevcut teknolojiye, bilinen yöntemlere ve tanımlanmış süreçlere göre eğitim faaliyetlerimizi en iyi biçimde, yapabildiğimize inanmalıyız.

Süreçlerde en iyi Yaptığımızı, yazılı hale getirirsek, standart olur. İşimizi ilk defada ve her defasında doğru yapabilmek, oluşturduğumuz yazılı standartlara (Prosedür, talimat vb) bağlı olduğunu da biliyoruz.

Mesleki eğitimde Kalitenin güvence altına alınması, mal ve hizmet gibi ürün üreten her işletmede olduğu gibi eğitim kurumlarının da, önemle üzerinde durulması gereken önceliklerdendir. Kalitenin güvence altına alınması için kullanılan yaygın yöntemlerden birisi dokümante edilmiş kalite yönetim sisteminin iç ve diş denetimlerle izlenmesidir.

Buradaki Kalite yönetim sistemi, ürünle ilgili amaca uygun süreçleri yerine getirmek üzere yeterli güveni oluşturmak için "yapılanın yazıldığı ve yazılanın uygulandığı” planlı ve sistematik süreçler bütünü olarak tanımlanmaktadır. İç ve dış denetimlerde, yazılanlar ve yapılanlardan uygunsuzluk gözlenmemesi durumunda mevcut kalite yönetim sistemi iyi çalışıyor demektir.

Ancak sürekli iyileştirmelerle mevcut durumun geliştirilmesi, yeni yöntem ve teknolojilerin devreye alınması, dokümantasyon revizyonunu ve sistem performansının yeniden değerlendirilmesini gerekli hale getirir. Kalite Güvence ile herhangi bir ürünün ya da mal ve hizmetin son kullanıcıya ulaşana ve kullanıcıdaki hukuki garanti ömrü bitene kadar tüm aşamalarda, tanımlanmış süreç, kişi ve bölümleri kapsar.

\section{Mühendislik eğitiminde kalite anlayışı;}

Yükseköğretim Kurumları “Ĕğitim işimizi nasıl oluşturmaltyız ki, en iyisi olsun?” sorusunun cevabını kalite olarak görmelidir.

Tanımdaki "Işsimizil" kelimesiyle asıl faaliyeti olan eğitimi temel alır. Eğitim için topluma ve paydaşlarına sunduğu 3 ayrı faaliyet grubuyla eğitim hizmetini sunar.

1. Eğitim-Öğretim faaliyetleri,

2. Araştırma faaliyetleri ve

3. Yönetim (İdari) hizmetleri olarak.

"En iyisi olsun" tanımıyla, mevcut, teknolojiler, bilinen yöntemler ve yönetmelikler çerçevesinde işlerimizi eksiksiz yapmak ve ortaya çıkan problemleri aşarak, mevcut durumu iyileştirip yani sürekli iyileştirme ile işini en son teknoloji ve en iyi biçimde yapmayı amaç edinir. 
“Eğitim işimizi nasıl oluşturmaltyız?" sorusunun cevabı aslında Kalitenin sürekli iyileştirmeye açık bir tanımıdır. Yapılan işlerin süreçleri doğru tanımlanmalıdır. Her eğitime ait faaliyet, mevcut imkânlara göre geliştirilerek en iyi biçimde yapılabilmelidir.

\section{1.Ĕ̆itim-öğretim faaliyetlerinde, kalite kriterlerinin oluşturulmasına ait iç değgrlendirme sorulart:}

- Programların kalitesinin değerlendirilmesi ve güvenceye alma (Mezunlar, İşverenler, aileler, Paydaş katılımı vb.) durumu.

- Program mezunları ve mesleki yeterlilikleri, Türkiye Yükseköğretim Yeterlilikleri Çerçevesiyle uyumu var mı?,

- Öğrencinin devamını veya sınava girmesini engelleyen haklı ve geçerli nedenlerin oluşması durumunu kapsayan açık düzenlemelerin varlığı ve eşit uygulanması durumu nasıl?

- Özel yaklaşım gerektiren öğrenciler (engelli veya uluslararası öğrenciler vb) için düzenlemeler

- Öğrencinin Kabulü ve Gelişimi, Tanınma ve Sertifikalandırma durumunun açık biçimde tanımlanmış olması ve başarının sürdürülebilirliği nasıl destekleniyor?

- Yurt içi ve yurtdışı eğitim kurumları arasında öğrenci hareketliliği (Farabi, Erasmus vb) ile ilgili düzenlemeler açık ve etkin uygulanıyor mu?

- Eğitim-öğretim kadrosunun yetkinlikleri (çalışma alanı/akademik uzmanlık alanı vb.) ile ders içeriklerinin örtüşmesi, atama, terfi ve mesleki gelişimleri takip edilmekte mi?.

- Fiziki ortamlar, Öğrenme Kaynakları (laboratuvar, internet), Erişilebilirlik ve Destekler, (staj, psikolojik destek, sağlik, yemekhane, yurt, spor alanları, kulüpler vb)

\subsection{Araştırma ve Geliştirme faaliyetlerinde, kalite kriterlerinin oluşturulmasına ait iç değerlendirme sorulart:}

- Kurumun araştırma stratejisi, hedefleri ve bu hedeflerin gerçekleşmesi takip edilmekte mi?

- Kurum, araştırmada öncelikli alanları ile ilgili yaptığı araştırma faaliyetlerinin seviyesi nedir?

- Kurumun sahip olduğu uygulama ve araştırma merkezleri ve faaliyetleri, eğitim faaliyetlerine katk1ları bulunmakta mı?

- Kurum, araştırma stratejisi olarak disiplinler arası ve/veya çok disiplinli araştırma faaliyetlerini desteklemekte midir?

- Araştırma firsatları ile ilgili kurum içi gerekli bilgi paylaşımı ve duyuru yöntemi nedir?

- Verilen doktora derecelerinin çeşitliliği ve doktora öğrencilerinin yurtiçi ve yurtdış1 üniversitelerde öğretim görevlisi olarak işe başlama oranları takip edilmekte mi?

- Kurumun fiziki/teknik altyapısı ve mali kaynaklarının yeterliliği (proje desteği, bağış, sponsorluklar, paydaş desteği) incelenmekte mi?

- Araştırma kadrosunun yetkinliğinin geliştirilmesi, iyileştirmesi ve performansları takip edilmekte mi?

\subsection{Yönetim hizmetleri ile ilgili faaliyetler de, kalite kriterlerinin oluşturulmasına ait sorular:}

- Kurum Operasyonel süreçlerini (eğitim-öğretim ve araştırma) ve idari/destek süreçlerini nasıl yönetiyor?

- Kaynak yönetimi (mali, personel, taşınır, taşınmazlar vb) takip sistemi nedir?

- Bilgi Yönetim Sistemi, mezunlarla iletişim, veri güvenliği sağlanmış ve sürdürülebilir mi?

- Kurum Dışından Tedarik Edilen (Yemek, güvenlik, temizlik vb) Hizmetlerin Kalitesi nedir?

- Kurum, topluma karş1 sorumluluğunun gereği olarak, eğitim-öğretim, araştırma-geliştirme faaliyetleri de dahil verilerin kamuoyuyla paylaşımı ve güncelliği nedir?.

- İdari Birimlerin Yönetimin Etkinliği ve Hesap Verebilirliği, liderlik ölçümü yapılmakta mı? 
Yükseköğretimde mühendislik eğitimin kalitesinin arttırılması için yukarıdaki bu kriterlerin dışında programların durumuna göre farklı Akreditasyon programlarının denetimine de (MÜDEK, EUR-ACE vb gibi) girilebilir. Bazı programlara bu kriter soruları uymayabilir. Mühendislik eğitiminde sistem olarak genel kalite kriterlerine referans olacak temel standartlar neler olabilir diye incelendiğinde, giriş, eğitim süreci ve çıktı (mezunlar) olarak Şekil 1'de gösterilmiştir.

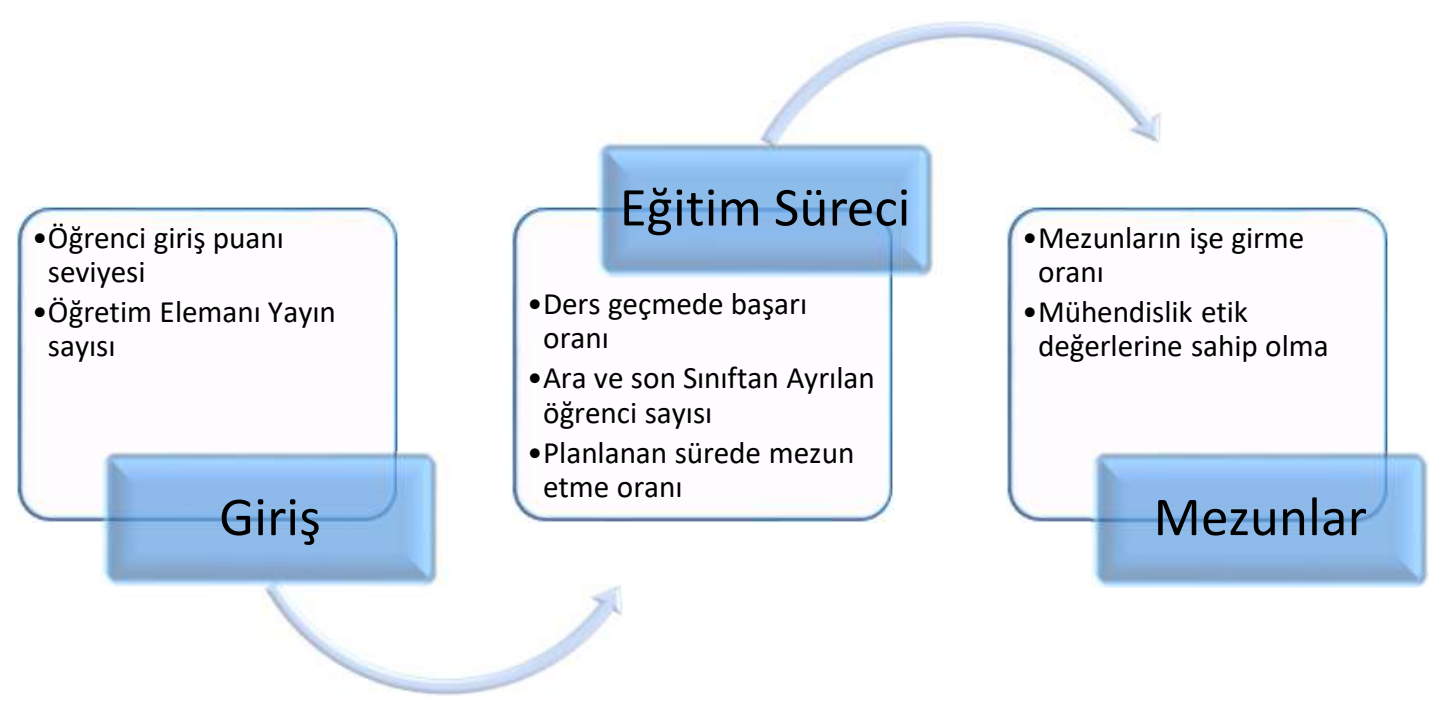

Şekil 1. Sistem olarak Mühendislik eğitimin de genel kalite ölçütleri

\section{Metodoloji}

Çalışma İstanbul'da eğitim faaliyetinde bulunan bir Üniversitenin, Sağlık, Sosyal, Fen, Spor alanlarında Enstitü, Fakülte, MYO gibi değişik sayıda birimleri mevcuttur. Temel eğitim standartlarından hangileri takip edilebilir durumda olduğunu genel durumunu incelemek üzere bir soru formu hazırlandı ve ilgili birimlere anket şeklinde gönderilerek cevaplanması istenmiştir. Bu sorulardan hangileri en çok eldeki mevcut verilere göre cevaplandığı ve hangilerinin cevapsız kaldığı değerlendirilerek, Kalite için gerekli temel standartlardan nelerin takip edildiği, nelerin takip edilmediği ortaya konmuştur. Yükseköğretimde kurumlara ait birimlerin kalite konusunda kriterleri uygulama düzeyi belirlenmiştir.

\subsection{Araştırmanın Uygulanması ve Örneklem}

Soru oluşturmak için birim yöneticileri ile ön görüşmeler yapılmış, Eğitim-öğretim faaliyetleri için 15 soru belirlenmiş, araştırma faaliyetleri için 9 soru, Yönetim sistemleri (İdari hizmetler) için 8 soru olmak üzere toplam 32 soru hazırlanmıştır.

Daha sonra bu formdaki soruları cevaplayan toplam 30 farklı birim değerlendirilmiştir. Birimleri oluşturan program ve bölüm sayıları dikkate alınmamıştır. Yani bir bölüm değerlendirme yaptı ise o birimin değerlendirmesi olarak dikkate alınmıştır. Örneğin sadece makine mühendisliği bölümü anketi cevapladı ise mühendislik fakültesi biriminin sonuçları olarak dikkate alınmıştır. Cevaplamayan 2 bölüm varsa, sonuçlarda dikkate alınmamıştır. Cevaplayan birim sayıları Şekil 2'de gösterilmiştir.

\section{2. Ölçüm aracı}

Ölçüm aracı Soru formunun değerlendirilmesi şeklindedir. Sorularımız 3 bölüm ve toplam 32 sorudan oluşmaktadır. Farklı bir araştırmanın ekinde birimlere gönderilmiştir. Elde edilen verilerin gerçek sonuçları burada açıklanmamıștır. Sadece cevap verilebilirlik değerlendirilmiş, en çok cevaplanan sorular sıralanarak listelenmiştir. 


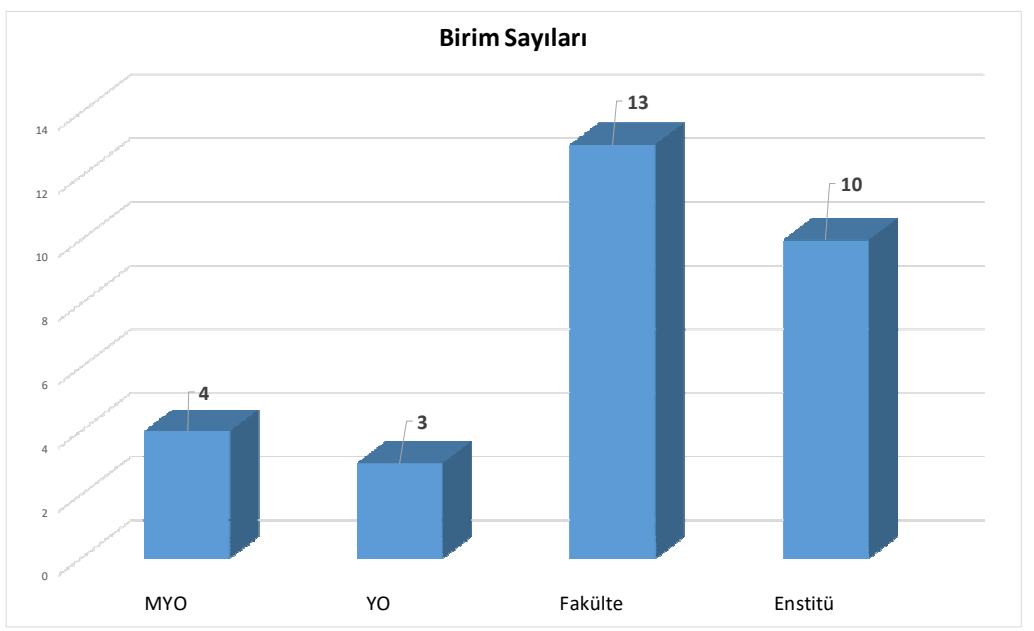

Şekil 2. Anketi cevaplayan birimlerin sayıları

Soruların analizinde ABC analizi kullanılmıştır. A grubu için ilk \%50'yi oluşturan sorular ki en çok cevaplanan sorular, B grubu için ikinci \%30'u oluşturan sorular ki bunlar kümülatif olarak orta sınıfı oluşturan cevaplanmış sorulardır. $\mathrm{C}$ grubu için ise son \%20'lik sorulardan oluşan grup yani en az cevaplanmış sorular olarak ele alınmıştır. Tüm soru başlıkları tanımlanarak, soru formlarındaki cevaplanan sorular "cevaplandı ve cevaplanmadı" şeklinde veriler olarak düzenlenmiştir.

\subsection{Evren}

Yükseköğretimde kalite güvence ölçütleri ve temel standartlar konusunda yapılan bu çalışma Türkiye'deki 206 Üniversitenin ilgili birimlerinde yapılabilir ve değerlendirilebilir. Ancak elde edilen verilerin değerlendirilmesi ve sonuçlarının açıklanması için hem üniversite rektörlüklerinden ve hem de yükseköğretim kurumundan izin alınması gerekir. Bunun zaman alacağı için burada sadece İstanbul'da faaliyette bulunan bir üniversitenin ilgili birimlerinde, hazırlanan temel standartlara ait soruların cevaplanabilirliği test edilmiş ve cevap verilenler ile verilmeyenler şeklinde tasnif edilmiştir.

\section{Bulgular}

$\mathrm{Bu}$ bölümde araştırma sonucunda elde edilen verilerin değerlendirmesi yapılarak, şekiller ve tablolar yardımıyla sorular ve cevapları açıklanacaktır.

\subsection{Yükseköğretimde kalite güvence ölçütleri için temel standartlar:}

a. Eğitim-Öğretim faaliyetleri için hazırlanan 15 soru ve birimlerin cevaplama oranı Tablo.1 verilmiştir.

Tablo 1. Eğitim-Öğretim Faaliyetleri Temel standartları

\begin{tabular}{|c|c|c|}
\hline $\begin{array}{l}\text { Sira } \\
\text { No }\end{array}$ & EĞiTIM-ÖĞRETIM FAALIYETLERI & $\begin{array}{c}\text { Cevaplanma } \\
\text { oranı }\end{array}$ \\
\hline 1 & Bölümlerin planlanan sürede mezun verme oranı nedir? (\%) & $83,3 \%$ \\
\hline 2 & Ders veren öğretim elemanı başına düşen öğrenci sayısı? & $86,7 \%$ \\
\hline 3 & Birimlerde eğitim için kullanılan sınıflardan 1m2'ye düşen öğrenci sayısı nedir? & $80,0 \%$ \\
\hline 4 & Kadrolu öğretim elemanına düşen öğrenci sayısı? & $86,7 \%$ \\
\hline 5 & 1m2 Laboratuvara düşen öğrenci sayısı? & $66,7 \%$ \\
\hline 6 & 1 Tuvalet sayısı başına düşen öğrenci sayısı kaçtır? & $76,7 \%$ \\
\hline 7 & Kitabı olan öğretim elemanı sayısı? (branşında yapılan yayın) & $70,0 \%$ \\
\hline 8 & Son bir yılda birimin düzenlediği kongre, sempozyum ve konferans sayısı nedir? & $70,0 \%$ \\
\hline 9 & Burs alan öğrenci sayısı (özel + devlet) nedir? & $46,7 \%$ \\
\hline 10 & Öğrenci kulüplerine üyelik oranı nedir? & $50,0 \%$ \\
\hline 11 & Kayıt yenileyen öğrenci sayısı kaçtır? - ORAN & $76,7 \%$ \\
\hline 12 & Sınav sonrası notlarına itiraz eden öğrenci sayısı \% kaçtır? & $73,3 \%$ \\
\hline 13 & Öğrencileriniz hangi ünvanla bölümünüzden mezun olmaktadır? & $86,7 \%$ \\
\hline 14 & Mezunlarınızın hemen iş bulabilme oranı nedir? & $66,7 \%$ \\
\hline 15 & Hedefleriniz periyodik takip ediliyormu? & $73,3 \%$ \\
\hline
\end{tabular}


$\mathrm{Bu}$ soruların, birimler tarafından cevaplanabilirliği grup grup incelenmiştir. Cevaplanma oranı en çoktan en aza doğru Tablo 2'de sıralanmıştır.

Tablo 2. Eğitim-Öğretim Faaliyetleri Temel standartları cevaplama sıralaması

\begin{tabular}{lc}
\multicolumn{1}{c}{$\begin{array}{c}\text { Sı́ra } \\
\text { No }\end{array}$} & $\begin{array}{c}\text { Cevaplanma } \\
\text { oranı }\end{array}$ \\
2 Ders veren öğretim elemanı başına düşen öğrenci sayısı? & $86,7 \%$ \\
4 Kadrolu öğretim elemanına düşen öğrenci sayısı? & $86,7 \%$ \\
13 Öğrencileriniz hangi ünvanla bölümünüzden mezun olmaktadır? & $86,7 \%$ \\
1 Bölümlerin planlanan sürede mezun verme oranı nedir? (\%) & $83,3 \%$ \\
3 Birimlerde eğitim için kullanılan sınıflardan 1m2'ye düşen öğrenci sayısı nedir? & $80,0 \%$ \\
6 1 Tuvalet sayısı başına düşen öğrenci sayısı kaçtır? & $76,7 \%$ \\
11 Kayıt yenileyen öğrenci sayısı kaçtır? - ORAN & $76,7 \%$ \\
12 Sınav sonrası notlarına itiraz eden öğrenci sayısı \% kaçtır? & $73,3 \%$ \\
15 Hedefleriniz periyodik takip ediliyormu? & $73,3 \%$ \\
7 Kitabı olan öğretim elemanı sayısı? (branşında yapılan yayın) & $70,0 \%$ \\
8 Son bir yılda birimin düzenlediği kongre, sempozyum ve konferans sayısı nedir? & $70,0 \%$ \\
5 1m2 Laboratuvara düşen öğrenci sayısı? & $66,7 \%$ \\
14 Mezunlarınızın hemen iş bulabilme oranı nedir? & $66,7 \%$ \\
10 Öğrenci kulüplerine üyelik oranı nedir? & $50,0 \%$ \\
9 Burs alan öğrenci sayısı (özel + devlet) nedir? & $46,7 \%$
\end{tabular}

ABC analizi uygulandığında En çok cevaplanan ve birimlerin sahip olduğu verilere yada takip edilen konulara ait sorular grubu olarak A grubu kümülatif toplamda ilk \%50'yi oluşturan grup olarak değerlendirilmiştir. Bu grup \%80 ile \%86 cevaplanma oranına sahiptir. B grubu kümülatif toplamda \%30'u oluşturan, ortalarda bir değerlendirmeye sahip sorular olarak değerlendirilmiştir. Konu ile ilgili takip istenirse veriler hızlı bir şekilde elde edilebilir durumdadır, zira $\% 76$ ile $\% 70$ arası bir cevaplanma oranına sahiptir. C grubu ise son \%20'yi oluşturan yani Birimlerin \%66'nın altında bir cevaplama oranı olan sorulardır. Örneğin "Burs alan öğrenci sayısı nedir?" diye sorulan soruya \%46,7 oranında birim cevap vermiştir. Eğitim-Öğretim Faaliyetlerine ait ABC analizi Tablo 3’te gösterilmiştir.

Tablo 3. Eğitim-Öğretim Faaliyetleri soruları ABC analizi

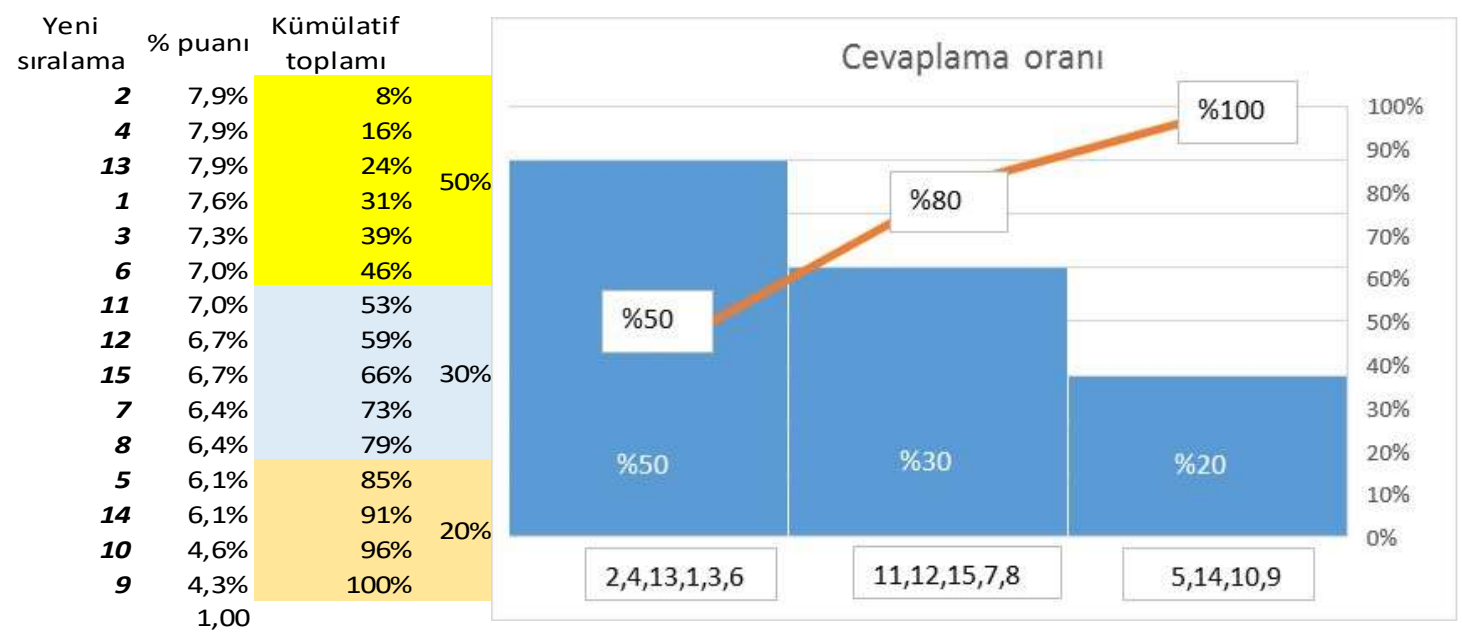

b. Araştırma faaliyetleri için hazırlanan kalite güvence kriterlerine ait 9 soru ve birimlerin cevaplama oranı Tablo.4'te verilmiştir. 
Tablo.4. Araştırma Faaliyetleri soruları cevaplanma oranı ve yeni sıralama

\begin{tabular}{clc}
$\begin{array}{c}\text { Yeni } \\
\text { Sıralama }\end{array}$ & \multicolumn{1}{c}{ ARAŞTıRMA FAALIYETLERi Soruları } & $\begin{array}{c}\text { Cevaplanma } \\
\text { oranı }\end{array}$ \\
$\mathbf{2}$ & En çok araştırma projesi alınan kurum? (BABKO, TÜBITAK, vb) & $73,3 \%$ \\
$\mathbf{4}$ & Birimde son bir yılda öğretim elemanlarının yaptığı yayın sayısı nedir? (tasnif edilmemiş) & $60,0 \%$ \\
$\mathbf{3}$ & Biriminize ait periyodik yayın sayısı nedir? (dergi, süreli yayın, bülten vb.) & $56,7 \%$ \\
$\mathbf{6}$ & Öğretim elemanlarının onaylanmış ve halen yürüttükleri araştırma proje sayısı nedir? & $56,7 \%$ \\
$\mathbf{8}$ & Öğretim elemanı değişim programıyla yurt dışına giden veya gelen öğretim elemanı sayısı kaçıı? & $50,0 \%$ \\
$\mathbf{7}$ & Biriminizde son bir yılda kaç uluslararası (Yurtdışı) araştırma projesi alındı? & $40,0 \%$ \\
$\mathbf{9}$ & Bölümün sahip olduğu sertifikalar (ISO9001, ISO17024, MÜDEK vb) & $30,0 \%$ \\
$\mathbf{1}$ & Biriminizde öğretim elemanı başına düşen araştırma fonu tutarı nedir? (x1000\$) & $26,7 \%$ \\
$\mathbf{5}$ & Periyodiklere ve arşivlere yıllık erişim sayısı nedir? (Elektronik ortamda-internetten) & $23,3 \%$
\end{tabular}

$\mathrm{ABC}$ analizine göre 2,4, ve 3. Sorular ilk \%50 ile A grubunu oluşturmuştur. B grubu ise 6 . Ve 8 . Sorular ile \%30'luk grubu oluşturmuştur. \%40 ve altında cevaplanma oranına sahip 4 soru $\mathrm{C}$ grubunu yani $\% 20^{\prime}$ lik son dilimi oluşturup, kümülatif toplamdaki yerini almıştır. Analizde, sorulara ait sıra numaraları ve \% puan ile Kümülatif toplam Tablo 5'te gösterilmiştir.

Tablo 5. Araştırma faaliyetleri sorularının cevaplanma oranına ait ABC analizi

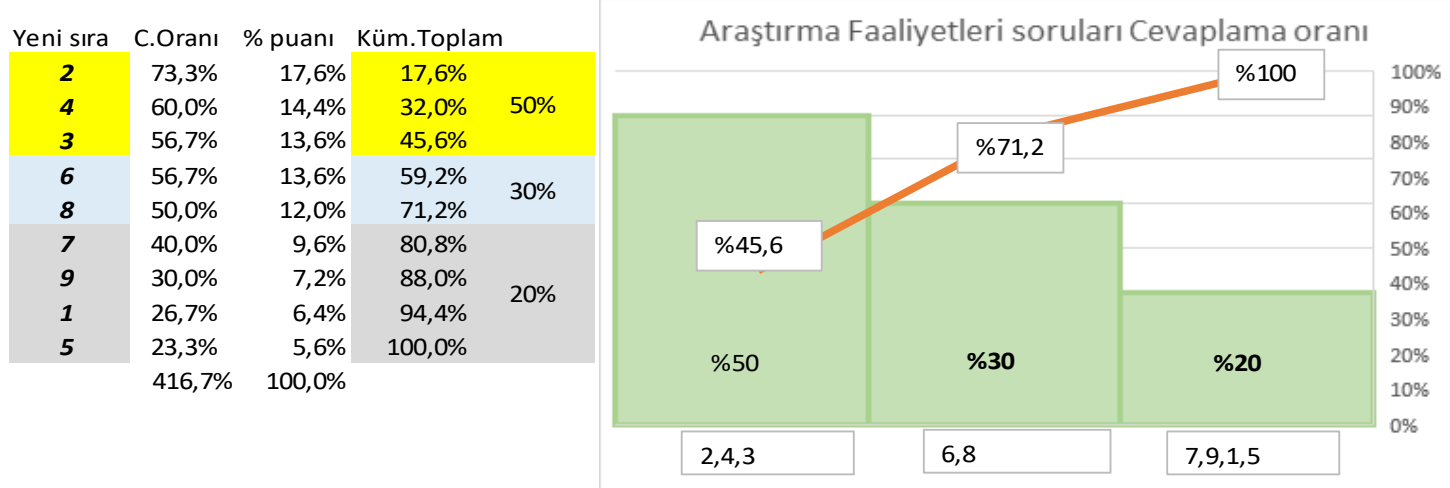

c. İdari hizmetlerle ilgili hazırlanan kalite güvence kriterlerine ait 8 soru ve birimlerin cevaplama oranı Tablo.6' da verilmiştir.

Tablo.6. Yönetim sistemi faaliyetleri sorularına ait cevaplanma oranı ve yeni sıralama

\begin{tabular}{|c|c|}
\hline YÖNETIM SISTEMI (IDARI HIZMETLER) FAALIYETLERI Soruları & $\begin{array}{c}\text { Cevaplanma } \\
\text { oranı }\end{array}$ \\
\hline 4 Görev yapan 1 büro personeline düşen öğrenci sayısı kaçtır? & $73,3 \%$ \\
\hline 2 Servislerden yararlanan personel yüzdesi nedir? & $70,0 \%$ \\
\hline 5 İdari personelin kullanım alanı? ( kaç m2) & $66,7 \%$ \\
\hline 6 Sendikalı personel sayısı nedir? (\%) (Öğretim elemanları dahil) & $63,3 \%$ \\
\hline 1 Ortalama günlük olarak yemekten yararlanan öğrenci yüzdesi nedir? & $50,0 \%$ \\
\hline 3 Biriminizde güvenlik görevlisi başına düşen öğrenci sayısı nedir? & $43,3 \%$ \\
\hline 7 Yurtlar ya da öğrencinin kaldığı otel benzeri barınma yerleriniz var mı ve kaç yataklıdır? & $40,0 \%$ \\
\hline 8 Kalite ile ilgili dokümantasyona sahipmisiniz? (P-Prosedür, T-Talimat vb) & $36,7 \%$ \\
\hline
\end{tabular}

İdari hizmetler, kurumların hizmetlerini daha iyi sunabilmek için genellikle dışarıdan alınan hizmetler olarak daha fazla göze çarpmaktadır. Temizlik hizmetleri, Güvenlik hizmetleri, yemek hizmetleri, servis hizmetleri, barınma vb gibi. Burada hazırlanan sorular ön görüşmelerden elde edilen sorular olup, farklı sorularla konu detaylı ele alınabilir yada bazı birimler için kullanımı mümkün değilse gereksiz sorular olarak da düşünülebilir. ABC analizi Tablo.7'de verilmiştir. 
Tablo.7. İdari hizmetlere ait soruların $\mathrm{ABC}$ analizi

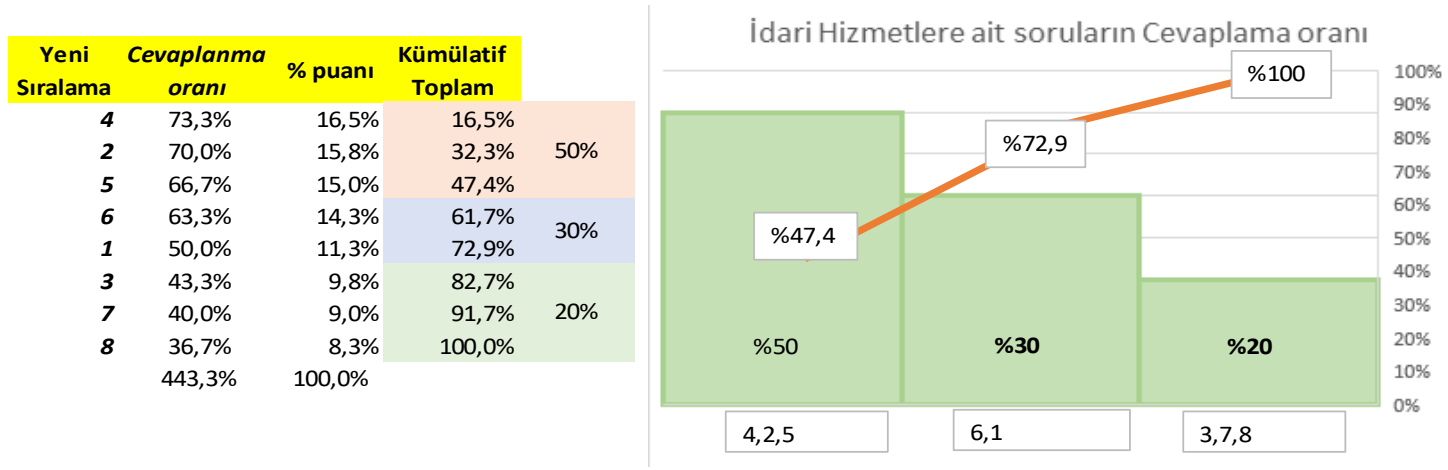

\section{2. Çalışmanın yorumu:}

Her 5 yılda bir yönetmelik [3] gereği bütün yükseköğretim kurumları dış değerlendirme almak durumundadır. Kurumların ve birimlerinin denetim öncesi yapılması gerekenleri gözden geçirmesi, unutulanları hatırlamaları ve eğitimleri özelinde nasıl yapılabileceğini değerlendirmesi önemlidir. Hazırlanan sorular her birim için uygun olmayabilir. Tıp için olması gerekenler, mühendislik için uygun olmayabilir. Bu bakımdan sorular değişebilir. Tartışılabilir.

Aynı kurumda, farklı birimlerde öğrenciye yaklaşım, sunulan hizmetler çok farklı olmamalıdır. Adil paylaşımın yapıldığı kalite güvence ölçütleriyle tespit edilebilir. 50 kişinin barındığı bir yurtta, 10 birim var ve sadece 1 birim öğrencileri yararlanıyorsa, uzak-yakın ayırımı gözetilmediyse, bu haksızlığın nasıl oluştuğu araştırılabilir. Hiç yararlanamayan ihtiyaç sahibi öğrencilerin hakkını nasıl eşit koruyabiliriz? sorusu sorulmalidir.

Hazırlanan soruların çoğu, birim yöneticilerinin görüşü doğrultusunda oluşturuldu. $\mathrm{Bu}$ sorular yönetimde farkındalık ve bilinç oluşturmaya yönelik olurken, eğitimi daha mükemmel nasıl yapabiliriz sorusunda genel durumunu ortaya konması bakımından da önemlidir.

Hazırlanması gereken memnuniyet (Öğrenci, çalışan, öğretim elemanı, mezun vb) anketleri, her birimin kendi sorunu olarak görülmelidir. Genel ve tek merkezden yapılan anketler farklı birimlerin sorunlarının tam çözümüne yönelik olamamaktadır.

Kurumun psikolojik destek birimi, sağlık hizmetlerinin zamanında ve yeterince verilmesi, özel öğrencilerin ihtiyaçlarının karşılanıyor olması, sportif alanların kullanımı ve kolay erişilebilir olması. Bilişim sistemlerinin yaygınlaşması, bilgiye kolay ve hızlı erişim, iletişim kolaylığ araştırma ortamları, sosyal etkinlikler vb daha birçok konuda sorular olabilirdi. Geniş bir araştırma çalışması ile bu mümkündür.

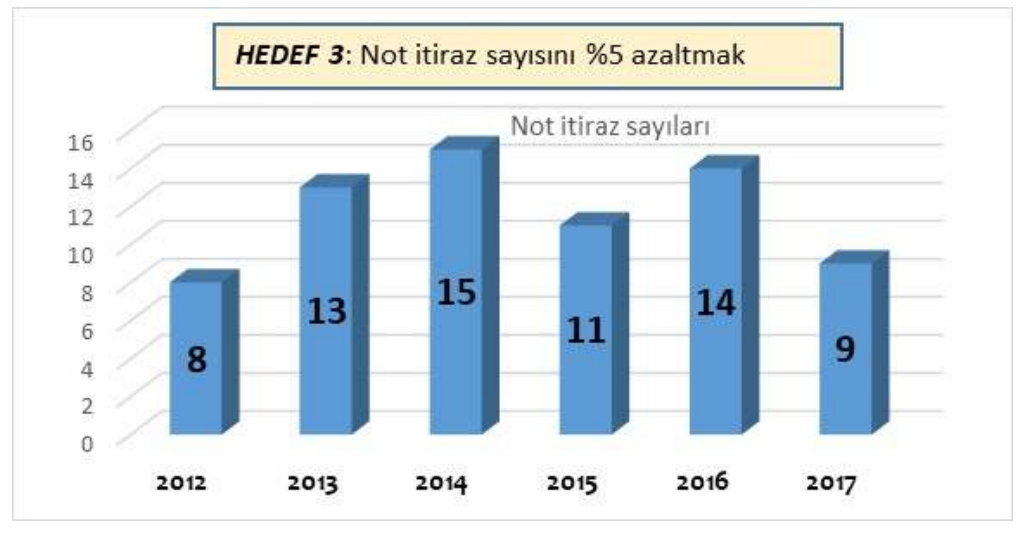

Şekil.3. Not itiraz sayılarına ait yıllar itibarılla hedef takibi

Dijital dönüşümün başladığ 1 ve Hedeflerle yönetimin öne çıktığı günümüzde, kurumlarda bu kalite güvence ölçütlerinden yararlanarak yeni hedefler konabilir, hedefleri takip ederek sürekli 
iyileştirmelerde bulunulabilir. Örneğin, not itiraz sayısını geçmiş yıllarda takip ederek hedef olarak izlemek. (Şekil.3.) iyileştirmeler için öneriler ve önlemler almak gibi

Kalite Güvence ölçütleri ve hedefler konusunda bu çalışmayla az da olsa fikir verebildiğimizi düşünüyoruz.

\section{Sonuç}

Yükseköğretim kurumlarında, kalite güvence ölçütleri veya temel standartların nasıl oluşturulması gerekliliği, genel olarak ele alınmış, mühendislik eğitimleri için benzer kriterler değerlendirmede dikkate alınarak ayrıca MÜDEK ve EUR-ACE (European Accreditation of Engineering Programmes) etiketi ile mühendislik programlarının ulusal, sektörel ve program yeterlilikleri odaklı kalitesi güvence altına alınabilmektedir. Diplomalardaki EUR-ACE etiketi ile Mühendislik eğitimleri Hem Avrupa standartlarına hem de uluslararası yüksek standartlara sahip oldukları belgeleniyor. Böylece Avrupalı işverenler tarafından tanınmaları da güvence altına alınmış oluyor.

Ağrı'daki bir mühendislik eğitimi ile İstanbul'daki bir mühendislik eğitiminin temel standartları elbette bölge ve yöreye özgü farklılıkları olacaktır. Ancak temel standartlar olarak kabul edilen ölçütlerle birimler ve bölümler hakkında bir fikir sahibi olunabilmelidir. Örneğin "öğretim elemanı başına düşen öğrenci sayısı” biliniyor olmalıdır. Gerek Yükseköğretimde kalite güvence kriterleri gerekse (EUAEuropean University Association) Avrupa üniversiteler birliği kalite kriterleri şartları, kurumları belli bir kalite düzeyine getirebilmektedir.

Çalışmamızda, yöntem olarak, sorun çözmede kullanılan ABC (pareto) analizi ile durum açıklanmıştır. Çözüme en düşük orandan yola çıkarak, sürekli iyileştirme çalışmaları başlatılmalı yada farklı yöntem ve çözüm kullanılmalıdır.

Dijital çağda özellikle büyük kurumların öğrenci sayılarının saniyelerle değiştiği ve bilgilerin anlık alınması artık mümkün olabilmektedir. Yükseköğretim kurumları da bu tür verilere anlık ulaşabilir duruma gelmiştir. İstenilen veriler anket çalışması yerine internet üzerinden yazılımlarla alınabilir.

Her seviyede eğitim kurumu, kendi kalite güvence ölçütlerini belirleyebilir. Ancak hangi kurumun daha iyi durumda olduğu, hangi birimlerin, programların geliştirilmesi gereklilikleri bu rasyolar ile kendi değerlendirmelerine göre ele alınabilir. Bu değerlendirmeler kurumlar arası bir rekabet aracı olarak düşünülmemelidir. Yükseköğretim kalite kurulu bu konuda üzerine düşenleri fazlasıyla yapmaya gayret gösteriyor. Kurumların kalite komisyonları da kurulla senkronize biçimde görevlerini zamanında yapar ve takip ederse yükseköğretimde kalite güvence başarılı bir şekilde genel anlamda sağlanacaktır.

\section{Kaynaklar}

[1] http://notoku.com/egitim-ogrenme-ve-ogretme/\#ixzz4M74e0MiC (04.10.2016)

[2] http://www.ogretmen.info/ogretmenlik_yeterlikleri ogretme.asp (30.07.2018)

[3] Resmi Gazete, Yükseköğretim kalite güvencesi yönetmeliği, sayı 29423, 23.Temmuz.2015 